\title{
Kenyan Government Initiatives in Slum Upgrading
}

\section{Leah Muraguri}

\section{(2) OpenEdition}

Journals

Electronic version

URL: https://journals.openedition.org/eastafrica/534

DOI: 10.4000 /eastafrica.534

ISSN: 2790-1076

\section{Publisher}

IFRA - Institut Français de Recherche en Afrique

\section{Printed version}

Date of publication: 1 September 2011

Number of pages: 119-127

ISSN: 2071-7245

\section{Electronic reference}

Leah Muraguri, "Kenyan Government Initiatives in Slum Upgrading", Les Cahiers d'Afrique de l'Est / The

East African Review [Online], 44 | 2011, Online since 07 mai 2019, connection on 28 juin 2022. URL: http://journals.openedition.org/eastafrica/534 ; DOI: https://doi.org/10.4000/eastafrica.534

This text was automatically generated on 9 December 2021.

Les Cahiers d'Afrique de l'Est / The East African Review 


\title{
Kenyan Government Initiatives in Slum Upgrading
}

\author{
Leah Muraguri
}

\section{Introduction}

1 Kenya, like other countries, has witnessed an unprecedented increase in urban population over the past fifty years. This has posed a great challenge to urban economies which have been unable to cope with the increasing demand for essential services such as housing, health and education. As a result, more urban dwellers in Kenya live in poverty and reside in overcrowded slums that lack basic amenities to sustain a minimum level of living.

2 By 1999, the proportion of the urban population in Kenya had increased of $34.5 \%$, affirming that one out of every three Kenyans currently lives in urban areas (Government of Kenya, 1999). This percentage is expected to increase to

$350 \%$ by the year 2015. This rate of urbanization and the inability of our urban economies to match the pace have contributed immensely to the proliferation of slums and informal settlements.

In Nairobi, an estimated 1.5 million people live in informal settlements, roughly $60 \%$ of the city's official census population of 2.5 million (Census 1999). These 1.5 million people are confined to an area of less that $5 \%$ of total municipal residential land. Segregation policies in the colonial era, a post-independence policy of slum clearance and a more recent lack of equitable and defined land and urban development policies have shaped Nairobi slums, like Kibera, into their present state.

5 To reverse this trend, the Government of Kenya, in collaboration with other stakeholders, initiated two programmes: the Kenya Slum Upgrading Programme (KENSUP) in 2004 and the Kenya Informal Settlement Improvement Project (KISIP) in June 2011. The programmes are aimed at improving the livelihoods of people living and working in slums and informal settlements. This entails promoting, facilitating, and where necessary, providing security of tenure, housing improvement, income 
generation and physical and social infrastructure. The actual target is to improve the livelihoods of at least 1.6 million households living in slums (5.3 million slum dwellers) by the year 2020. This will be done at an estimated total cost of KSh 883.76 billion or USD 11.05 billion.

\section{The Kenya Slum Upgrading Programme (KENSUP)}

6 The Kenya Slum Upgrading Programme (KENSUP) is a collaborative initiative that draws on the expertise of a wide variety of partners in order to redress the issue of slums. The Government of Kenya executes and manages the programme while the Ministry of Housing and the relevant local authorities implement it. Civil society partners, participating local communities and the private sector complement and support their efforts. KENSUP's aim is to improve the livelihoods of people living and working in slums and informal settlements in the urban areas of Kenya through the provision of security of tenure and physical and social infrastructure as well as providing opportunities for housing improvement and income generation.

7 Implementation is underway in all provincial headquarter Kenyan cities/towns. The Government plans to expand the programme to other areas. This programme covers selected urban slums beginning with those in Nairobi, Mavoko, Mombasa and Kisumu. It targets all provincial headquarters and secondary towns with a population of 20,000.

8 The main principles of KENSUP are decentralization, sustainability, democratisation and empowerment, transparency and accountability, resource mobilization, secure tenure, expansion and up-scaling, partnerships and networking. With regard to the institutional set-up, there is a Settlement Executive Committee (SEC) composed of people from the community where the government is operating. SEC is the main driver of this programme since the government wants the people to know what it is deciding. Other institutional aspects of KENSUP include: Settlement Project Implementation Unit, Project

9 Implementation Unit, Programme Secretariat (in the Ministry) and the Interagency Steering Committee (IASC) composed mainly of accounting officers in key relevant Ministries, Local Authorities, United Nations Human Settlements Programme (UNHABITAT) and other development partners.

\section{KENSUP Goals and Objectives}

10 To achieve its goal and objectives, KENSUP has adopted the following strategic interventions:

- Community organization and mobilization;

- Shelter improvement: security of tenure or residential security, housing development and improvement;

- Preparation of city/town development strategic and land use master plans;

- Provision of physical infrastructure: sewerage system, water supply and sanitation, access roads, storm water drainage, electricity and street lighting;

- Provision of social infrastructure: schools, health centres, community centres and recreational facilities;

- Provision of secure tenure and residential security 
- Environmental and solid waste management: garbage collection and treatment system, cleaning of the Ngong river;

- Employment and income generation: markets, skills enhancement, micro-financing and credit systems;

- Addressing issues of HIV/AIDS: HIV education and awareness, counselling and testing centres, HIV dedicated clinics;

- Conflict prevention and management in the targeted informal settlements

- Prevention of proliferation of slums.

\section{Kenya Informal Settlement Improvement Project (KISIP)}

11 The Kenya Informal Settlement Improvement Project (KISIP) is a new initiative started by the Government in collaboration with the World Bank, Swedish International Development Agency (SIDA) and French Agency for Development (AFD). KISIP will focus on improving living conditions in existing informal settlements by investing in infrastructure and strengthening tenure security. It will also support the Government of Kenya (government counterpart funding is 10\%) in planning for future urban growth in a manner that prevents the emergence of new slums. KISIP will be implemented in 15 municipalities within five years from June 2011 at a cost of USD 165 million.

The project comprises four components namely:

- Institutional strengthening and programme management of the Ministry of Housing, Ministry of Lands and the participating Local Authorities (LAs): the Government does not take this aspect for granted but seeks to strengthen its own capacity.

- Enhancing tenure security: This involves planning, surveying and issuance of titles. Several activities that will be undertaken under this component include preparation of guidelines for informal settlements, establishing databases on land tenure, community organisation and mobilisation, preparation of development plans including determination of settlement boundaries, detailed mapping, identification and verification of beneficiaries based on agreed eligibility criteria, preparation of local physical development plans, issuance of letters of allotment to households/groups, surveying of individual plots and preparation of registry index maps, registration and issuance of titles to households or groups. The government would like to have a model/guideline for informal settlements whereby the identification will be mostly done by the community. Some require group titles while others need individual titles. The government would like to do the mapping and provide secure tenure.

- Investing in infrastructure and service delivery. The Government will invest in roads, bicycle paths, pedestrian walkways, street and security lights, waste management, water drainage, sanitation, green spaces, platforms etc. in the informal settlement spaces. KENSUP will work on the housing whereas KISIP will deal mainly with this infrastructure.

- Planning for urban growth. Lack of adequate planning is a challenge. Through this component, the Government will provide technical assistance to the municipalities. The goal of this initiative is to take measures that will reduce or prevent slums. 


\section{Slum Upgrading Achievements}

\section{Physical Mapping and Planning of Soweto East}

13 In Nairobi, the implementation of the programme commenced in Kibera informal settlement, specifically in the pilot area of Soweto East village. Various preparatory activities have been undertaken in this village including socio-economic and physical mapping, enumeration of residents, preparation of a physical land use plan and the construction of an access road.

Due to the high densities in the village, a strategy was developed in which residents were temporarily relocated in order to pave way for upgrading of the settlement. In view of this, two hectares of decanting site situated across the settlement were obtained for purposes of constructing housing units to serve as temporary relocation premises for the Kibera residents. Relocation housing was constructed and around 1,800 households were relocated.

The site consists of 600 housing units comprising of 17 blocks of three roomed houses i.e. two bedrooms, a sitting room, a kitchen and washing area. About 1,200 households from Kibera Soweto East were relocated to Lang'ata awaiting re-development of the area. Modalities for the construction of houses are being worked on. However, the process has been slowed down by a court case.

Figure 1: Lang'ata public housing site

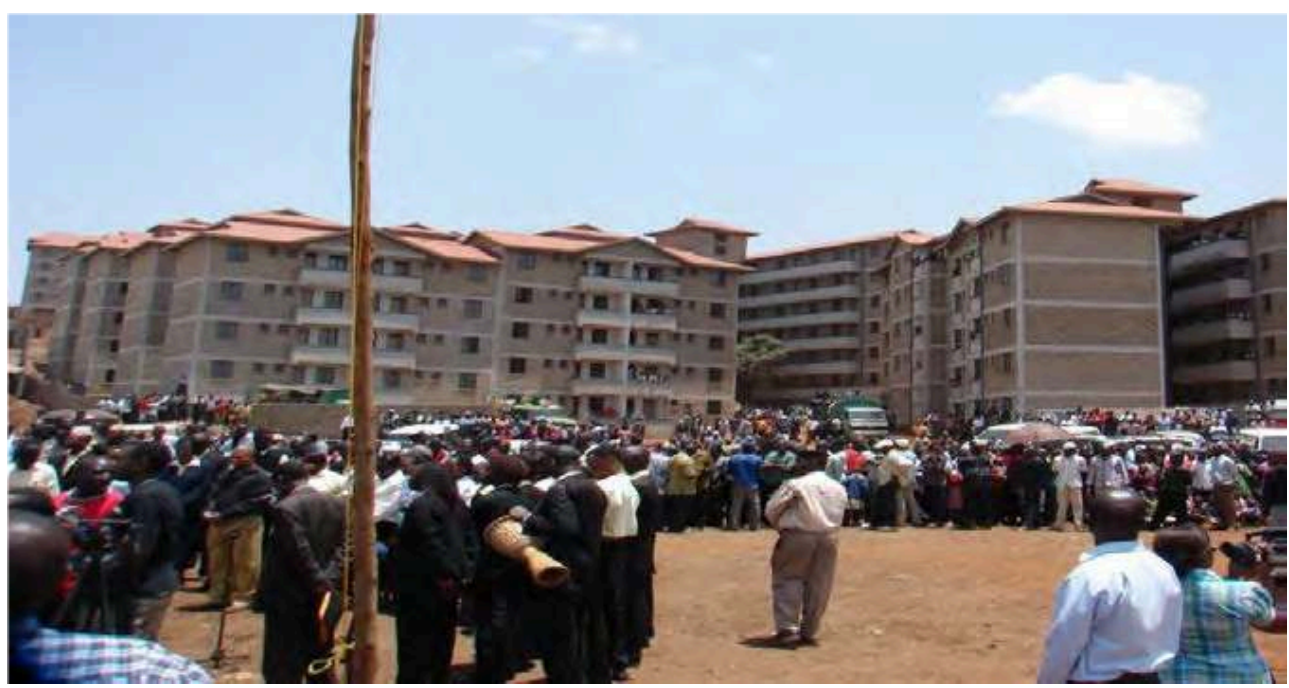

Source: Leah Muraguri (2008).

\section{Social and Physical Infrastructure Projects}

16 In Kisumu, Mombasa, Nyeri, Kakamega, Nakuru and Nairobi, the social and physical infrastructure projects include classrooms, health centers, Early Childhood Development units, rehabilitation of social halls and market stalls and upgrading of roads. The settlements include: Kisumu (Bandani, Magadi, Nyalenda and Manyatta) and Mombasa (Ziwa la Ngombe). 
Figure 2: Market stalls in Manyatta-Kisumu
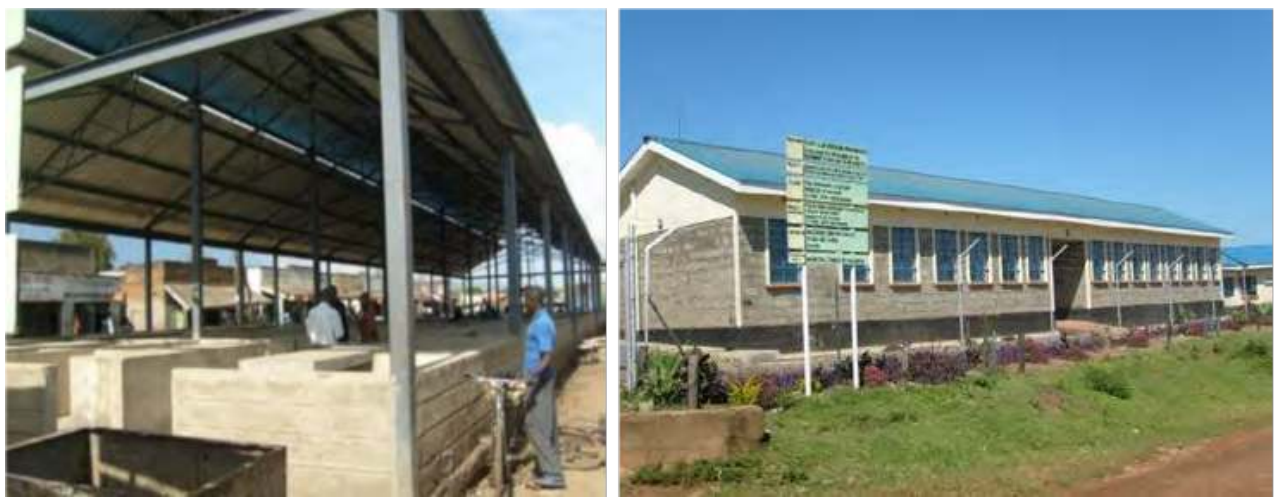

Source: Leah Muraguri (2008)

Figure 3: Classrooms at Kakamega Amalemba slums

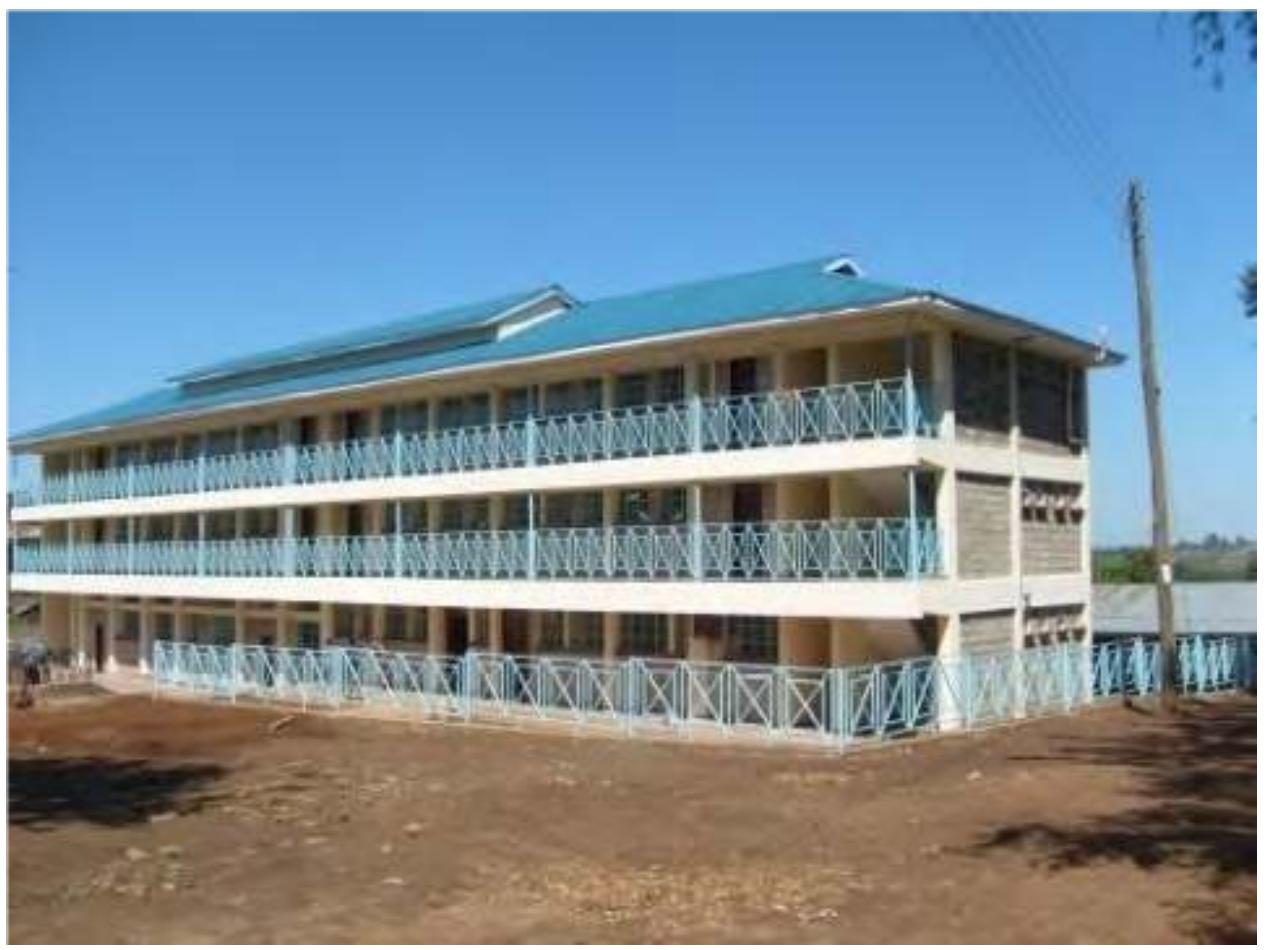

Source: Leah Muraguri (2008) 
Figure 4: Access Road at Kibera slums

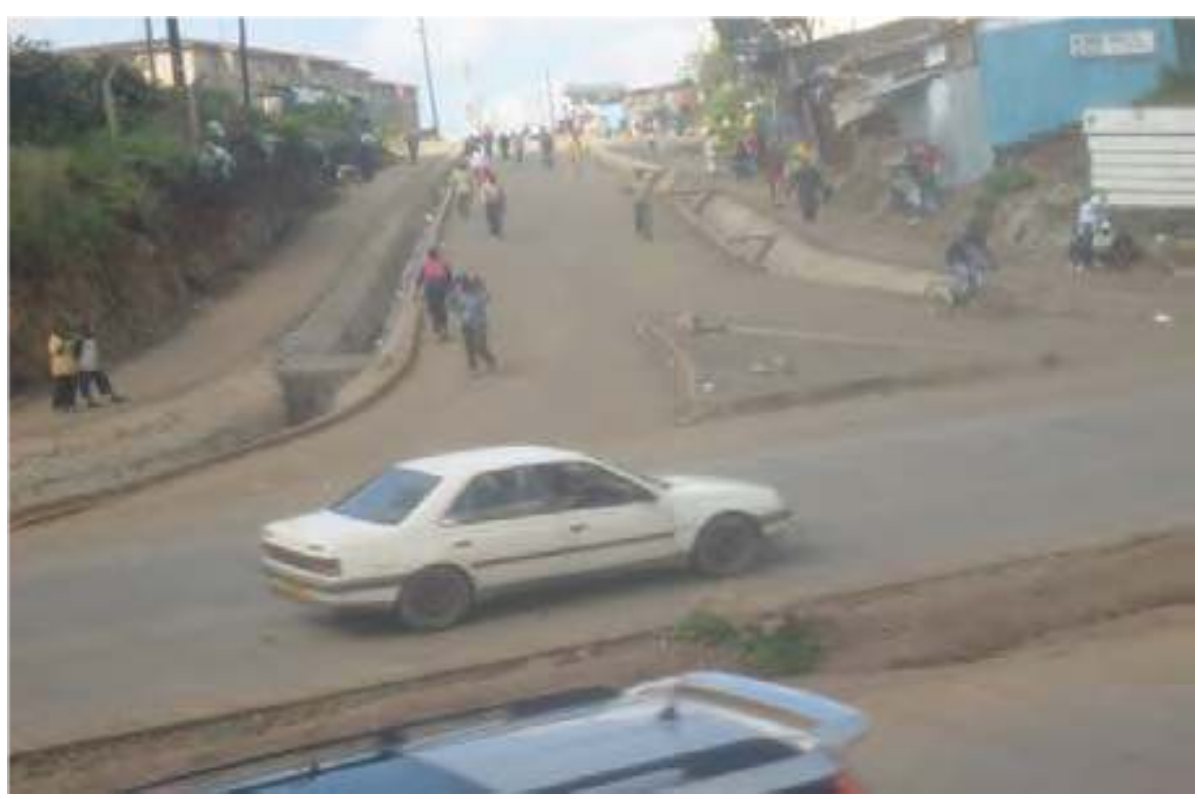

Source: Leah Muraguri (2008)

\section{Development of Housing in Mavoko (Mavoko Sustainable Neighborhood Project-SNP)}

17 With 412 mixed housing units and associated physical infrastructure on 21.64 hectares of land under the sustainable neighbourhood concept; this project comprises of a selfsustained neighbourhood in Mavoko-Athi River, one of the municipalities within Nairobi metropolitan area, with one primary school, one nursery school, one social hall, one health center, one police station and one market center. 


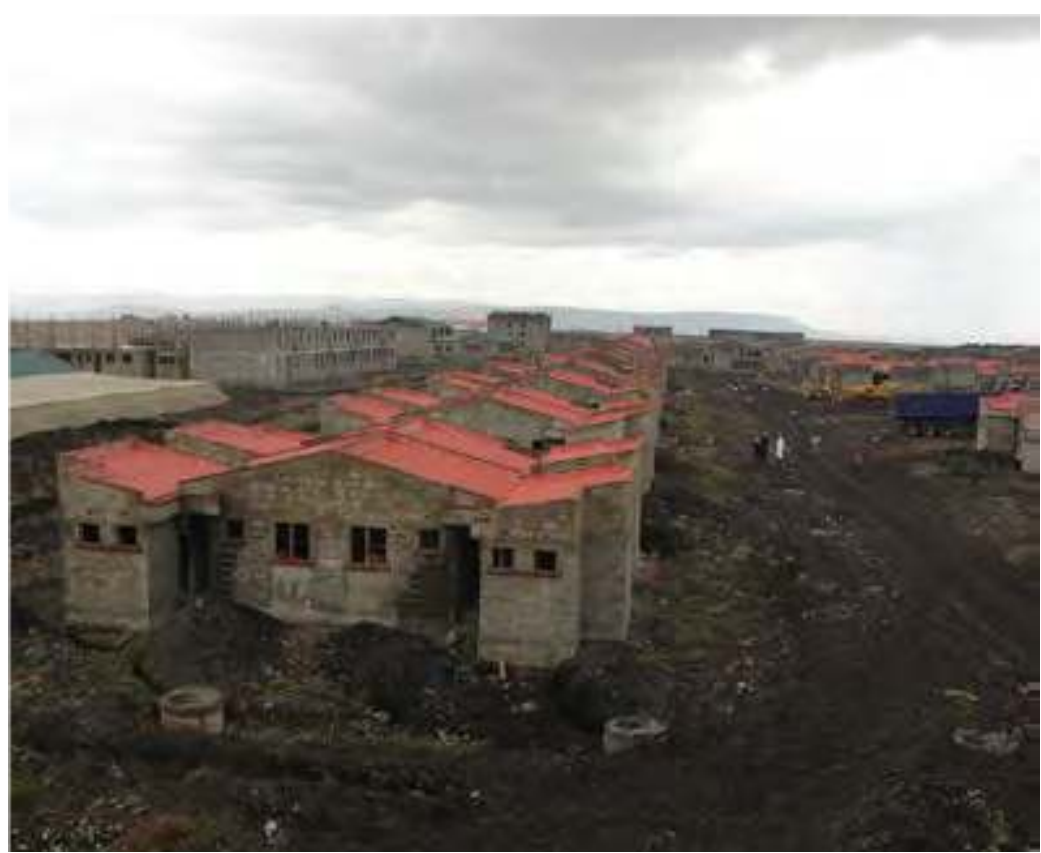

Source: Leah Muraguri (2008)

\section{Capacity Building}

18 Another achievement has been in the facilitation of formation of Housing Cooperatives Societies, SECs, community groups and capacity building in slums. Housing cooperative societies have been identified as the best mechanism for participation and transfer of ownership of KENSUP projects to the settlement community. Twenty housing cooperatives have been formed and registered in Nairobi, Kisumu, Kakamega and Mombasa (KENSUP project areas).

19 The SEC is one of the key institutions in the implementation process formed in towns where KENSUP has projects. Through the SEC, the programme assists in capacity building of the communities so as to prepare them to be part of the project implementation. The communities are involved at all stages of the programme from the identification of the projects to its commissioning.

\section{Challenges to Slum Upgrading in Kenya}

Complexities of slum settlements with regard to tenure arrangements: Slum settlements have no formal tenure arrangements. Their high densities, haphazard developments, lack of planning, poor housing, lack of infrastructure and the religious, cultural and political inclinations involved are some of the conditions that pose a challenge in proposing the type of tenure that is be best suited to the residents' situation.

22

Conflicts between tenants and landlords: conflicts abound between these two groups of residents due to their varied interests. The fact that nearly $85 \%$ of slum dwellers are 
tenants is a unique aspect of Kenyan slum settlements which greatly hampers progress in slum upgrading.

Varied political, cultural and religious inclinations amongst the residents, and those of their leaders, have contributed in creating suspicion and mistrust amongst the residents thus slowing down decision making.

Competing interests of various groups e.g. Non-Governmental Organisations (NGOs), Community-Based Organisations (CBOs), Faith-Based Organisations (FBOs), Central Government, Local Authorities and donor agencies. These stakeholders have their own interests in the slum, most of which conflict therefore they are a major drawback to the programme.

25 Lack of adequate land. There is limited land space to cater for all residents within the slum settlements and scarcity of land for re-location where necessary. Land ownership is private in most settlements. Lack of planning of informal settlements by the local authorities is a challenge towards upgrading the settlements.

Partnership concepts also have the disadvantage of generating several parallel activities that often derail the implementation schedules. There are also issues with regard to governance and involvement of communities in decision making which have various complexities.

\section{BIBLIOGRAPHY}

Government of Kenya. 1999. Population and housing census: Analytical report on population projections, VII. Nairobi: CBS, MFP.

\section{ABSTRACTS}

This article discusses two Kenyan government initiatives in slum upgrading: the Kenya Slum Upgrading Programme (KENSUP) and the Kenya Informal Settlement Improvement Project (KISIP). It gives the objectives, strategies and components of each programme. The article focuses on the KENSUP programme, presenting the achievements of this slum upgrading initiative to date and sums up with the challenges facing slum upgrading in Kenya.

\section{INDEX}

Geographical index: Kenya 


\section{AUTHOR}

\section{LEAH MURAGURI}

Land Economist, Director of Slum Upgrading Department and Coordinator of Kenya Slum

Upgrading Programme (KENSUP) at the Ministry of Housing of Kenya, Nairobi, Kenya. 